\title{
ENCONTROS E DESENCONTROS: UMA BREVE REFLEXÃO SOBRE O LONGO DIÁLOGO ENTRE O POÉTICO E O FILOSÓFICO
}

\author{
Gisele Batista Candido 1 \\ Universidade de São Paulo (USP) \\ (iD) https://orcid.org/0000-0001-7182-3192 \\ E-mail: giselebc@gmail.com
}

\section{RESUMO:}

Considerando retrospectivamente os desdobramentos da filosofia, é possível observar que, antes de reconhecer e reafirmar as singularidades de seu exercício, o discurso filosófico tem sua origem intimamente associada à poesia. Evidenciando alguns momentos de cisão e outros momentos de contato entre o discurso poético e o discurso filosófico, o presente ensaio visa abordar e refletir sobre o diálogo entre esses dois discursos ao longo do tempo. Nesse horizonte, consideraremos estrategicamente os trabalhos de autores como Homero, Platão, Goethe, F. Schlegel e Schelling, a fim de evidenciar as oscilações e salientar alguns movimentos específicos dentro desse longo diálogo.

PALAVRAS-CHAVE: Poesia; Filosofia; Homero; Platão; Goethe; F. Schlegel, Schelling.

\section{DISTANCE AND PROXIMITY: A SHORT REFLECTION ON THE LONG DIALOGUE BETWEEN THE POETIC AND THE PHILOSOPHICAL}

\begin{abstract}
:
Considering the history of Philosophy, we can see that, before recognizing and stating the peculiarities of its practices, the philosophical discourse was born in intimate connection to poetry. By exploring moments of tension and proximity between poetic and philosophical discourses, the present essay is a reflection on this relationship over time. In order to do so, we focus on the works of authors such as Homer, Plato, Goethe, F. Schlegel, and Schelling as a strategy to show variations and emphasize some specific movements within this long dialogue.
\end{abstract}

KEYWORDS: Poetry; Philosophy; Homer; Plato; Goethe; F. Schlegel; Schelling.

${ }^{1}$ Doutora em Filosofia pela Universidade de São Paulo (USP), São Paulo - SP, Brasil. Pós-doutoranda em Filosofia na Universidade de São Paulo (USP), São Paulo - SP, Brasil com bolsa CNPQ.

CANDIDO, Gisele Batista. Encontros e desencontros: uma breve reflexão sobre o longo diálogo entre o poético e o filosófico. Griot : Revista de Filosofia, Amargosa - BA, v.18, n.2, p.114-128, dezembro, 2018. 
- O que a filosofia - replicou ele -, o que a superioridade fria dessa ciência tem a ver com a poesia?

- A poesia - respondi seguro da minha opinião - é o começo e o fim dessa ciência. Ela se origina da poesia de um ser divino infinito, como Minerva da cabeça de Júpiter. E desse modo, afinal, o incompatível conflui novamente para ela, para a fonte misteriosa da poesia.

(Hölderlin, F. Hipérion ou o eremita na Grécia, p. 85).

Em um dos momentos de sua obra, Fernando Pessoa (1988-1935) escreve sobre as diferenças e semelhanças entre o filósofo e o poeta: "Não nos espantemos, que uma coisa é o poeta a outra o filósofo ainda que sejam a mesma" (PESSOA, 2001, p. 250). Tal espirituoso oxímoro dialético - que distingue uma disposição da outra para imediatamente, contrariando a lógica dedutiva, concluir que elas são análogas - pode soar menos paradoxal e mais conciliador se pressupormos que, ainda que sejam dois discursos distintos, filosofia e poesia conservam algo em comum, uma ligação primordial e necessária. A fim de refletir sobre essa possibilidade, este ensaio considerará alguns momentos pontuais que marcaram de forma diversa o longo - e nem sempre harmônico - convívio entre os discursos filosófico e poético.

Considerando retrospectivamente os desdobramentos da filosofia, é possível observar que, antes de reconhecer e reafirmar as singularidades de seu exercício, o discurso filosófico tem sua origem intimamente associada à poesia. Com efeito, além de compor uma narrativa épica sobre homens que convivem com criaturas míticas em um mundo marcado pela presença e intervenção de deuses, os versos de Homero ${ }^{2}$ também se revelam como um ambiente para experiências de teor filosófico, à medida que afiguram e desenvolvem questões indissociáveis à condição humana. Na Odisseia, por exemplo, diante de um universo dominado por forças incompreensíveis e inexoráveis, o que se destaca é sobretudo a astúcia que faz Ulisses agir racionalmente; refletir sobre sua condição de modo a contornar ou lidar com o inexorável, seja ele natural ou sobrenatural. Atena, deusa conhecida por sua astúcia e intelecto, evidencia esses aspectos quando fala ao herói homérico em questão:

Simulador sem defeitos seria quem te superasse/ em qualquer sorte de astúcia, ainda mesmo que fosse um dos deuses./ Ó astucioso e matreiro incansável, nem mesmo na pátria/ resolverás pôr à margem, de vez, esta sorte de embustes/ e de artimanhas falazes, que tanto condizem com tua alma?/ Bem; mas deixemos de lado essas coisas, porque ambos na astúcia/ somos peritos. No meio dos homens salientas-te sempre/ pelos discursos e planos; no círc'lo dos deuses sou célebre/ por minha astúcia e saber. (HOMERO, 2001, p. 232 - canto 13 versos 293 - 99).

Conforme Adorno (1903 - 1969) e Horkheimer (1895 - 1973), em a A dialética do esclarecimento, "As aventuras de que Ulisses sai vitorioso são todas elas perigosas seduções que desviam o eu da trajetória de sua lógica. (...) O recurso do eu para sair

\footnotetext{
2 Assim como todas as datas de nascimento e morte de todos os filósofos da antiguidade clássica citados nesse ensaio, a exata data da possível existência de Homero é incerta. Heródoto dizia que Homero viveu 400 anos antes de seu próprio tempo, isto é; em torno de 850 a.C. Considerando a data em que foi concebida a Ilíada e a Odisseia, os estudos modernos localizam a existência de Homero entre os últimos anos do século IX a.C. e o século VIII a.C. Entretanto, alguns estudos recentes defendem que sua vida transcorreu no século VII a.C., uma vez que, de acordo com Gregory Nagy, os textos homéricos foram inicialmente fixos apenas no século VI a.C.
}

CANDIDO, Gisele Batista. Encontros e desencontros: uma breve reflexão sobre o longo diálogo entre o poético e o filosófico. Griot : Revista de Filosofia, Amargosa - BA, v.18, n.2, p.114-128, dezembro, 2018. 
vencedor das aventuras: perder-se para se conservar, é a astúcia" (ADORNO E HORKHEIMER, 1985, p. 56, 57). No canto XII da Odisséia, por exemplo, acompanhamos o episódio em que Ulisses encontra as Sereias. Ciente de que o canto dessas Seriais atrairia ele e seus homens para uma armadilha mortal, fazendo-os jogar sua embarcação contra as pedras, seguindo os concelhos de Circe, Ulisses instrui todos os homens de seu navio a tampar os ouvidos com cera, para assim passar incólumes pelo canto sedutor dessas criaturas. No entanto, o próprio Ulisses se nega a tampar seus ouvidos. Antes, sem fugir a essa aventura, ele pede que seus homens o amarre firmemente ao mastro do navio para que, mesmo seduzido pelo canto das sereias, ele seja incapaz de atirar-se ao mar atrás delas. Diante desse desafio, Ulisses poderia ter mudado a rota de sua embarcação, de modo a não passar por Capri - a ilha das sereias - ou então ele poderia ter tampado seus ouvidos, como fizeram os seus marinheiros. Entretanto, ele prefere viver essa experiência, orientado, todavia, por sua astúcia, que o leva a diminuir drasticamente seus riscos.

É possível compreender Ulisses como o herói que representa a antecipação alegórica do triunfo da razão. Nas palavras de Franklin Leopoldo e Silva:

\begin{abstract}
A astúcia representa em Ulisses a tomada de consciência, pelo homem, de que ele pode vencer a natureza e o sobrenatural por via de uma força especificamente humana, que não se mede fisicamente, e que seria o poder de raciocinar e de calcular as possibilidades, de modo a fazer com que a desvantagem que ele possui inevitavelmente de início possa se transformar justamente no fator que lhe permitirá superar a vantagem do inimigo. Neste sentido, a Odisséia foi analisada por Adorno e Horkheimer como a alegoria da supremacia da razão humana sobre as forças naturais e até mesmo sobrenaturais. A viagem de Ulisses e os perigos que ele enfrenta representariam, nesse caso, a constituição da racionalidade como o instrumento privilegiado pelo qual o homem vai triunfar sobre o mundo encantado. A astúcia de Ulisses seria a primeira figura da razão e do seu papel de dominar o irracional, ou aquilo que em princípio se lhe opõe. E as vitórias de Ulisses podem ser entendidas, alegoricamente, como a demonstração de que a razão é capaz de superar todos os obstáculos e impor-se como o único critério de relação com o mundo, critério que mostra ao mesmo tempo a supremacia da razão. (SILVA, F. L. Mito e razão na "Odisséia" in Portal Arethusa)
\end{abstract}

Ao considerar a formação do homem grego na antiguidade, Werner Jaeger, escreve que "Os mitos e as lendas heroicas constituem um tesouro inesgotável de exemplos e modelos da nação, que neles bebe o seu pensamento, ideais e normas para a vida" (JAEGER, W. 2013, p. 67). Para Werner Jaeger o discurso poético da Ilíada e da Odisseia apresentam uma forma de enlace entre a vitalidade e a desenvoltura filosófica-espiritual que foi fundamental para o processo de formação do homem grego. Ele explica esse fenômeno:

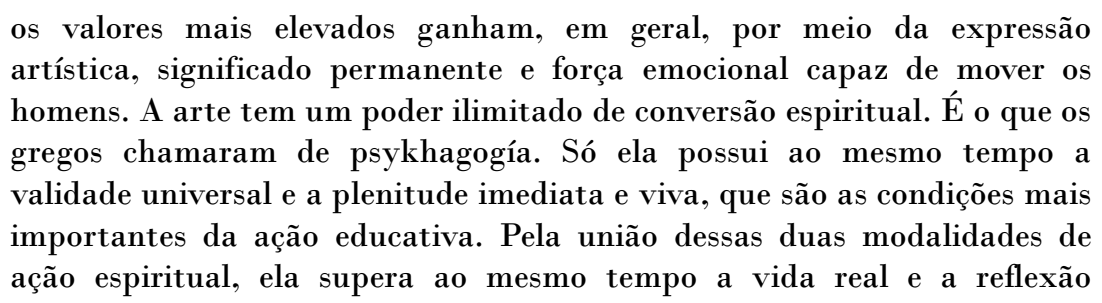

CANDIDO, Gisele Batista. Encontros e desencontros: uma breve reflexão sobre o longo diálogo entre o poético e o filosófico. Griot : Revista de Filosofia, Amargosa - BA, v.18, n.2, p.114-128, dezembro, 2018. 
filosófica. A vida possui a plenitude de sentido, mas a suas experiências carecem de valor universal. Sofrem demais a interferência do sucessos acidentais para que a sua impressão possa alcançar sempre o grau máximo de profundidade. A filosofia e a reflexão atingem a universalidade e penetram na essência das coisas. Mas atuam somente naqueles cujos pensamentos chegam a adquirir a intensidade de uma vivência pessoal. Daqui resulta que a poesia tem vantagem sobre qualquer ensino intelectual e verdade racional, assim como sobre as meras experiências acidentais da vida do indivíduo. É mais filosófica que a vida real, mas é, ao mesmo tempo, pela concentração de sua realidade espiritual, mais vital que o conhecimento filosófico. (JAEGER, W. 2013, p. 62).

A Ilíada e a Odisseia não são as únicas obras que deram voz para o diálogo entre o poético e o filosófico na antiguidade clássica. A Teogonia, poema cosmogônico de Hesíodo (750 a.C. - 650 a.C.), e as tragédias gregas também ilustram o princípio heterogênico do discurso filosófico, que tem o seu surgimento vinculado à poesia. Como espaço privilegiado para a exposição de problemáticas tão pertinentes à existência humana, essas obras poéticas pautaram inclusive as reflexões filosóficas de Platão, Aristóteles, Nietzsche, Heidegger, Adorno e tantos outros filósofos, até os dias atuais.

De uma forma mais direta, a poesia foi o veículo escolhido por alguns pensadores pré-socráticos para expor suas formulações, como Parmênides de Eléia (530 a.C. - 460 a.C.) e Empédocles de Agrigento (490 a.C. - 430 a.C.). Dispondo da forma poética para criticar, justamente, a pertinência da poesia de Homero e Hesíodo, o pensador Xenófanes de Colofão (570 a.C. - 475 a.C.) “escribió versos, elegías y yambos contra Hesíodo y Homero, haciendo burla de lo que habían dicho acerca de los dioses, y aun iba cantando sus versos en público" (LAERCIO, D. 1792, p. 224). Ao censurar com seus versos a forma perniciosa como esses rapsodos afiguravam os deuses (com vícios e defeitos), Xenófanes contribuiu com o clássico embate entre poetas e filósofos, influenciando Platão em seu processo de formalização do discurso filosófico a partir da crítica e distanciamento de práticas poéticas.

Desde seu início, a filosofia se vê às voltas com a poesia. Entre afastamentos e aproximações, esse envolvimento contribuiu para configurá-la ao longo de seus desdobramentos. Não é exagero pensar que a presença da poesia no discurso filosófico faz parte da própria construção do que entendemos por filosofia ${ }^{3}$. Ao considerar a relação entre o platonismo e a poesia, Lukács (1885 - 1971) dirá inclusive que: "o platônico diz suas palavras mais significativas quando escreve sobre o poeta" (LUKÁCS, 2015, p. 64). Quando caracteriza a filosofia, por exemplo, Platão (428 a.C. - 347 a.C.) precisa necessariamente distinguí-la da poesia. Esta, conforme podemos acompanhar nos diálogos de Íon, derivaria de instâncias sobre-humanas, divinas e dependeria da inspiração, não de algum tipo de conhecimento, para se estabelecer: "Pois coisa leve é o poeta, e alada e sacra, e incapaz de fazer poemas antes que se tenha tornado entusiasmado e ficado fora de seu juízo e o senso não esteja mais nele" (PLATÃO, 2011, p. 39). Já a filosofia ensejaria uma certa

\footnotetext{
3 Segundo Cláudio Oliveira, "A posição de Sócrates, como personagem de Platão, é a primeira a sustentar tal exclusão da poesia e da sofística do âmbito da filosofia. Esse ato é, de fato, o ato que define a própria constituição da filosofia. A filosofia se funda e se constitui por essa exclusão." (OLIVEIRA, 2011, p. 17)
}

CANDIDO, Gisele Batista. Encontros e desencontros: uma breve reflexão sobre o longo diálogo entre o poético e o filosófico. Griot : Revista de Filosofia, Amargosa - BA, v.18, n.2, p.114-128, dezembro, 2018. 
autonomia tanto em seus princípios quanto na forma como é conduzida, sem depender dos deuses, caberia ao homem buscar por si o caminho do conhecimento. Assim, a experiência poética, como uma espécie de inspiração sobrenatural, se diferenciará consideravelmente da epistème, enquanto possibilidade do conhecimento filosófico.

A ascensão da conduta racional, encarnada alegoricamente pelo herói da Odisseia, passa a servir de parâmetro para Platão diferenciar a poesia da filosofia. Lá, no entanto, as articulações da razão estavam a serviço da astúcia e do engodo, aqui ela deve conduzir à verdade e à virtude moral.

Além de sofrer censuras na dimensão moral - graças ao tipo de influência que os poetas exerciam sobre a polis, com versos repletos de exemplos nocivos que, no entanto, soavam de forma sedutora -, em $A$ República, a poesia também será apartada da filosofia por conta de suas características constitutivas miméticas, que, conforme Sócrates, lhe conferiam o mais alto grau de afastamento da verdade, estabelecido por uma relação corrompida com o mundo das Ideias:

Podemos, com razão, censurá-lo [o poeta] e considerá-lo o par do pintor. Assemelha-se a ele por só produzir obras sem valor, do ponto de vista da verdade, e assemelha-se também por estar relacionado com o elemento inferior da alma, e não com o melhor dela. Estamos, então, bem fundamentados para não recebermos num Estado que deve ser regido por leis sábias, visto que esse indivíduo desperta, alimenta e fortalece o elemento mau da alma e assim arruína o elemento racional, como ocorre num Estado que se entrega aos maus, deixando-os tornar-se fortes e destruindo os homens mais nobres. Diremos o mesmo do poeta imitador que introduz um mau governo na alma de cada indivíduo, lisonjeando o que nela há de irracional, o que é incapaz de distinguir o maior do menor, que, pelo contrário, considera o mesmos objetos ora grandes, ora pequenos, que só produz fantasias e se encontra a uma distância enorme da verdade. (PLAT ÃO, 1997 p. 334).

Os diálogos platônicos sem dúvida configuraram de maneira decisiva a cisão entre poesia e filosofia. Todavia, Platão não excluiu totalmente o uso de práticas poéticas no desenvolvimento de suas reflexões. A República, por exemplo, marca a expulsão, mesmo que provisória, dos poetas da polis platônica, mas ao mesmo tempo é arrematada pela narração de um mito por Sócrates, uma narrativa caracteristicamente poética ${ }^{4}$. Seja por necessidades propedêuticas, seja como forma de atrair e entreter seus espectadores, ou até porque a especulação estritamente racional se mostrou incapaz de dar conta de questões limites, o fato é que Platão se serviu de recursos poéticos para desenvolver e até arrematar seu discurso filosófico, como o mito de Er, que conclui $A$ República.

Suas duras críticas ao emprego do mito pelos poetas e rapsodos estariam, nesse contexto, mais relacionadas aos aspectos morais nocivos de seus versos e a

\footnotetext{
${ }^{4}$ Inúmeros autores, como Perceval Frutiger, Cassirer, Luc Brisson, foram animados ou desenvolveram estudos sobre o papel do mito na obra de Platão, considerando questões como a função, o sentido, o que pode ser classificado como mito, o que é alegoria, quais são e se há diferenças substâncias entre aquele e essa. Embora tenhamos ciência dos debates e estudos acerca do tema, no presente ensaio pretendemos apenas salientar o recurso à narração mítica enquanto uma forma de presença do discurso poético nos diálogos platônicos.
}

CANDIDO, Gisele Batista. Encontros e desencontros: uma breve reflexão sobre o longo diálogo entre o poético e o filosófico. Griot : Revista de Filosofia, Amargosa - BA, v.18, n.2, p.114-128, dezembro, 2018. 
forma mimética ${ }^{5}$ escolhida por eles para representá-los, que ao recurso em si. Para contornar esses problemas, ao lançar mão do uso do mito, Platão o submeterá ao crivo moral do bom exemplo e optará pela diegesis, uma espécie de narração simples, que não apela para a imitação. Em diversos momentos de seus escritos, Platão deixa de lado sua argumentação caracteristicamente dialética e passa a utilizar a narrativa mítica para exprimir suas ideias. O discurso mítico permite a Platão ir além dos limites do discurso racional, e expor teorias que excedem os domínios estritamente racionais. Enfim, sem romper de forma definitiva a relação primordial entre o poético e o filosófico, é sobretudo através do mito que a ponte entre esses dois discursos se sustentará em seus diálogos.

Talvez porque a crítica de Platão à poesia, bem como tudo o que isso envolve, tenha se destacado mais que a sua escolha de não excluir totalmente o discurso poético de suas reflexões, muitas vezes a tradição filosófica que se seguiu preferiu dar ênfase e continuidade ao projeto de delimitação de seu meio, elegendo para essa tarefa sobretudo a regularidade da razão, em detrimento da via, por assim dizer, intuitiva, tão privilegiada pela poesia. Entretanto, por mais que a ruptura provocada pela crítica platônica tenha configurado consideravelmente a maneira como a filosofia se singularizou e continuou a se desdobrar ao logo do tempo, nem por isso esse percurso é constituído apenas pelo distanciamento do poético. Oscilante, o longo diálogo entre esses dois meios também é composto por aproximações que transformaram a filosofia. Nesse ínterim, os autores que diretamente influenciaram e os que constituíram o movimento filosófico conhecido como Romantismo Alemão estão entre aqueles que abordaram e pensaram de forma mais radical a reaproximação dos dois discursos. Em uma disposição consideravelmente distinta daquela de Platão, eles entreviram no envolvimento íntimo entre filosofia e poesia um solo fértil e necessário para o renascimento e o desenvolvimento do discurso filosófico.

Se, por um lado, é sobretudo a censura direcionada a Homero que inaugura o distanciamento entre poesia e filosofia na antiguidade clássica, por outro lado, é também a obra de um poeta, Goethe (1749 - 1832), que inspira as reflexões sobre essa considerável reaproximação na modernidade. Opondo-se ao racionalismo desmedido ${ }^{6}$ e, em contrapartida, propondo uma compreensão orgânica e global do mundo e do homem em contínua formação (Bildung), a obra de Goethe foi abordada com entusiasmo pelos filósofos envolvidos com o Romantismo Alemão, que viriam a desenvolver reflexões atentas ao equilíbrio entre o sentimento e a razão na formação de um homem integrado à natureza, mediante a comunhão entre arte e filosofia.

Enquanto Platão recorreu a sua filosofia para criticar a poesia, Goethe recorre a poesia para criticar algumas características da filosofia. Aliás, ao contrário

\footnotetext{
5 Ainda que faça diversas críticas à mímeses poética, Platão não a condena totalmente. Enquanto concebe sua polis ideal, por exemplo, ele considerará seu uso sob certas condições filosóficas, éticas e políticas.

${ }^{6}$ Márcio Suzuki também escreve sobre essa postura crítica de Goethe: "Ele vê a filosofia com reticências, mas o faz com conhecimento de causa, pois estudou os sistemas filosóficos antigos e modernos e se muniu de uma concepção-de-mundo bastante rica e consistente. O problema da filosofia vem de mais longe: para o chamado préRomantismo alemão, também conhecido como Sturm und Drang, movimento em que ele se inseriu na juventude, a filosofia moderna integra um grande sistema de racionalização do mundo, que tem de ser combatido. $O$ Iluminismo constituiu o ápice desse esforço de dominação da natureza, e a crença no progresso das Luzes projeta nessa mesma natureza um finalismo técnico antropomórfico, como se a total racionalidade fosse o objetivo derradeiro a ser atingido pela história da humanidade." (SUZUKI, 2005, p. 202)
}

CANDIDO, Gisele Batista. Encontros e desencontros: uma breve reflexão sobre o longo diálogo entre o poético e o filosófico. Griot : Revista de Filosofia, Amargosa - BA, v.18, n.2, p.114-128, dezembro, 2018. 
de Platão, Goethe tinha em alta conta Homero e as narrativas míticas.

Em suas Conversações com Goethe, Eckermann fala sobre essa característica do poeta alemão: “À mesa com Goethe. Falamos de Homero. Notei que, nele, a ação dos deuses está em conexão imediata com o real." Em um outro momento em diálogo com Goethe, sobre as figuras míticas do Fausto, Eckermann fala: "A Antiguidade eu disse - deve ser muito viva para o senhor, caso contrário não lhe teria sido possível chamar de volta à vida aquelas figuras todas em todo o seu frescor, nem utilizá-las e tratá-las com tanta liberdade como o fez." (ECKERMANN, 2016, p. 385, 441)

Já Schelling escreve sobre a natureza mitológica do Fausto de Goethe:

Tanto quanto se pode julgar o Fausto de Goethe pelo fragmento que dele existe, esse poema não é outra coisa que a essência mais íntima e mais pura de nossa época: matéria e forma criadas daquilo que toda a época continha, que ela estava ou ainda está gestando. Por isso se deve chamá-lo de um poema verdadeiramente mitológico (SCHELLING, 2001, p. 104).

Com seu Fausto, Goethe retoma um antigo mito alemão. $\mathrm{O}$ primeiro registro escrito da figura de Fausto data de 1587, quando o editor Spies publicou a Historia von Dr. Johann Fausten. Desde então Fausto se tornou uma figura mítica, simbolo das ambições humanas, retomada por inúmeros autores da literatura ocidental, como o próprio Goethe, Christopher Marlowe, Byron, Heinrich Heine, Thomas Mann, Valéry, Pessoa, entre outros.

Enquanto emblema da racionalização excessiva, o Fausto de Goethe tem como protagonista um homem, que dá nome a obra, cuja aspiração é refém de um apetite racional desmedido, que, sem a mediação de outras virtudes, se revela tão insustentável quanto devastador. Zombeteiramente, em um diálogo com Deus, Mefistófeles fala sobre tal condição: "Só vejo como se atormenta o humano ser./ Da terra é sempre igual o mísero deusito,/ Qual no primeiro dia, insípido e esquisito./ Viveria ele algo melhor, se da celeste/ Luz não tivesse o raio que lhe deste;/ De Razão dá-lhe o nome, e a usa afinal,/ Para ser feroz mais que todo animal." (GOETHE, 2010, p. 51)

Sobre sua condição, o próprio personagem de Fausto diz:

Ai de mim! Da filosofia/ Medicina, jurisprudência,/ E, mísero eu! da teologia,/ O estudo fiz, com máxima insistência./ Pobre simplório, aqui estou/ E sábio como dantes sou!/ De doutor tenho o nome e mestre em artes,/ E levo dez anos por estas partes,/ Pra cá e lá, aqui ou acolá/ Os meus discípulos pelo nariz./ E vejo-o, não sabemos nada! (GOETHE, 2010, p. 63).

Impulsionado por sua insaciável e desmedida sede de saber, em seu pacto com Mefistófeles, Fausto pede que sua sede de saber seja aplacada através do excesso, do acesso ao Todo. Pedido negado por Mefistófeles, que afirma ser próprio da natureza humana uma vida limitada. No entanto, diante dessa negativa, Fausto diz: "Mas que é que eu sou, se me é vedado, pois,/ Granjear da humanidade o diadema,/ Do Eu todo a aspiração suprema?" (GOETHE, 2010, p.177) Enfim Mefistófeles lhe responde: "No fim sereis que sempre sois./ Por mais que os pés sobre altas solas coloqueis,/ E useis perucas de milhões de anéis,/ Haveis de ser sempre o que sois." (GOETHE,

CANDIDO, Gisele Batista. Encontros e desencontros: uma breve reflexão sobre o longo diálogo entre o poético e o filosófico. Griot : Revista de Filosofia, Amargosa - BA, v.18, n.2, p.114-128, dezembro, 2018. 
2010, p.177)

Apesar de todas as riquezas, de todas os artifícios e estratagemas, todos os saberes, Fausto, bem como qualquer outro homem, sempre será aquilo que ele sempre foi, assim seu saber desmedido servirá apenas para atormentá-lo, alerta Mefistófeles.

Conforme Marcus Mazzari, essa desmedida instigada pelo saber insaciável faz com que

\begin{abstract}
Fausto assuma o papel titânico de representante de toda humanidade. Como lembra Schöne, essa aspiração incondicional pela totalidade encontra sua crítica nas palavras do Abbé ao final de Wilhelm Meister: 'Quem quiser fazer ou fruir tudo em sua plena humanidade, quem quiser associar tudo que lhe é exterior a tal espécie de fruição, este haverá tão somente de passar sua vida numa aspiração eternamente insatisfeita." (GOETHE, 2010, p.175).
\end{abstract}

Com Os anos de aprendizado de Wilhelm Meister, Goethe se tornou conhecido por inaugurar na Alemanha um novo gênero literário, o "romance de formação" (Bildungsroman), que privilegia a experiência de formação das potencialidades de seu protagonista, a partir das condições históricas e sociais que o cercam. A ideia de formação que é desenvolvida nesse romance perpassa e se reconfigura em inúmeros outros escritos de Goethe, e marca também os autores do Romantismo Alemão. Tanto que, em um de seus fragmentos, F. Schlegel (1772 - 1829) reconhecerá: "A Revolução Francesa, a doutrina-da-ciência de Fichte e o Meister de Goethe são as maiores tendências da época." (SCHLEGEL, F. 1997, p. 83)

Sob a influência dos escritos de Aristóteles (384 a.C. - 322 a.C.) e de outros filósofos ${ }^{7}$, Goethe se propôs a pensar o homem em íntima sintonia com a natureza, entrevendo correspondências, por assim dizer, estruturais entre tudo o que existe:

Feche os olhos, aguce os ouvidos, e da mais leve respiração ao mais selvagem ruído, do mais simples som à mais sublime harmonia, do mais violento e apaixonado grito às mais suaves palavras da doce razão, é somente a Natureza que fala, revelando sua existência, seu poder, sua vida e suas relações e estruturas, de tal modo que um cego, a quem é vedado o mundo infinitamente visível, é capaz de apreender no audível tudo o que é infinitamente vivo. (GOETHE apud WULF, 2016, p. 9).

Ao considerar a atuação da Natureza, o poeta alemão observa que cada ser, inclusive o homem enquanto parte dela, vive sob um processo de transformações e formação, que confere contornos específicos em harmonia com as limitações de cada

\footnotetext{
${ }^{7}$ Goethe inclusive escreveu um "Suplemento à poética de Aristóteles" em que, se opondo à visão moralizante que Platão tinha da Tragédia, ele "se afasta da perspectiva que considera a catarse a partir do efeito moralizador que provoca sobre o espectador e a interpreta como um ingrediente interno da composição mesma do poema trágico" (TOLLE, 2000, p. 123). Conforme Márcio Suzuki, "Em Aristóteles, quando uma matéria recebe uma determinação ou forma, ela passa de potência ao ato. Passar ao ato significa então alcançar uma completude, um acabamento, um termo. (...) Goethe vai se aproveitar largamente dessas observações de Aristóteles, de quem dizia que entendeu a natureza melhor do que qualquer autor moderno. O organismo só mostra sua forma e seu fim enquanto está atuando, ou inversamente, a atualidade é o que mais propriamente exprime a sua forma e o seu fim" (SUZUKI, 2005, p. 206). Em seu artigo Os anos de aprendizado de Goethe, Suzuki também escreve sobre as influências filosóficas do poeta, refletindo sobre o papel de Kant, sem deixar de considerar a importância de Espinosa, Jacobi, Herder, Schiller e outros na formação de Goethe.
}

CANDIDO, Gisele Batista. Encontros e desencontros: uma breve reflexão sobre o longo diálogo entre o poético e o filosófico. Griot : Revista de Filosofia, Amargosa - BA, v.18, n.2, p.114-128, dezembro, 2018. 
ser e ainda em articulação com o todo ${ }^{8}$.

Conforme a lógica goetheana, em detrimento dos limites de seu corpo, a girafa, por exemplo, tem seu pescoço alongado para suprir suas necessidades vitais e ambientais específicas. Seguindo essa lógica, aquilo que potencializa o desenvolvimento de determinada parte, é também o que faz com que outra parte permaneça latente; os limites delineiam a espécie. Esse processo harmônico não se restringe apenas ao domínio biológico, mas a todos, inclusive ao das artes ${ }^{9}$. Nesse contexto, os mitos, que para ele possuem a força atemporal de configurar igualmente questões e compreensões atuais, tem um papel interessante, pois podem afigurar virtuosamente o equilíbrio dessa dinâmica goetheana. $\mathrm{O}$ que Afrodite tem em beleza, ela deixa de ter em outros aspectos. Tal limitação não implica todavia em desvantagem. Sua beleza não seria tão evidente e determinante, se ela também sustentasse outras características marcantes, como a força ou a astúcia, em grau semelhante. Considerando ainda essa harmonia individual em articulação com o todo, se os deuses olímpicos não possuíssem potencialidades distintas e complementares, seria difícil manter o equilíbrio divino do Olimpo.

Goethe evidencia com sua obra a interação e as correspondências entre o microcosmo que é o homem e o macrocosmo que é o mundo. Para conhecer a si, o homem precisa necessariamente conhecer o mundo, e para conhecer o mundo, ele precisa conhecer a si. Sem se fechar em si e restringir o seu desenvolvimento à segurança da especulação racional, o homem de formação global - e não total - deve explorar suas distintas faculdades, o que inclui tanto a imaginação quanto o entendimento, razão e sensibilidade. A poesia será um espaço privilegiado para esse desenvolvimento abrangente, inclusivo e fértil, porquanto a criatividade fomentada por seu vínculo com o intuitivo e com a imaginação age expandindo os campos para a prospecção da razão e para a construção do amplo entendimento.

Enfim, assim como Platão olhava com receio para a poesia sem, no entanto, abandoná-la totalmente, Goethe também olhava com desconfiança para a filosofia, sem rejeitá-la por completo. Diferente, todavia, da crítica platônica que provocou o distanciamento entre uma e outra, a crítica do poeta alemão à racionalização desmedida do mundo e seu elogio à intuição estimulou seus interlocutores a considerar os benefícios da conciliação entre o discurso poético e o filosófico, à medida que tal disposição privilegiava uma formação capaz de integrar organicamente o homem ao mundo.

Em um de seus fragmentos, F. Schlegel escreve: “... toda arte deve se tornar ciência e toda ciência, arte; poesia e filosofia devem ser unificadas" (SCHLEGEL, F. 1997, p.38). Como fonte de inspiração e motivo de crítica, o idealismo alemão também influenciou o movimento Romântico, que, por um lado, viu sobretudo na

\footnotetext{
${ }^{8}$ Sobre como Goethe compreendia a articulação entre a forma e o fim, Walter Benjamin escreve: "A definição kantiana do orgânico como uma finalidade cujo fim não se situa fora, mas sim dentro da criatura, que constitui uma finalidade em si, esta definição correspondia aos conceitos de Goethe. A unidade do belo, mesmo do belo natural, é sempre independente dos fins - nisso, Kant e Goethe estão de acordo" (BENJAMIN, 2009, p. 149) 9 Suzuki escreve: "Quando se passa do mundo mineral para o vegetal, do vegetal para o animal, e destes para o universo artístico ou literário, o que ocorre é metamorfose. Isso permite pensar que cada domínio seja ao mesmo tempo ligado aos demais sem perder sua delimitação e autonomia. É assim que o processo artístico já não é concebido como mimese pura e simples, mas como transmutação, "imitação formante", na expressão de Moritz aprovada por Goethe." (SUZUKI, M. 2005, p. 217)
}

CANDIDO, Gisele Batista. Encontros e desencontros: uma breve reflexão sobre o longo diálogo entre o poético e o filosófico. Griot : Revista de Filosofia, Amargosa - BA, v.18, n.2, p.114-128, dezembro, 2018. 
Crítica da Razão Pura de Kant (1724 - 1804) e na Doutrina da Ciência de Fichte (1762 - 1814) o desenvolvimento, à partir da reflexão crítica e rigorosa, das possibilidades da consciência. Por outro lado, viu também as limitações de um sistema especulativo excessivamente teórico, restrito à formalidade da linguagem filosófica ${ }^{10}$, em frequentar de maneira mais sensível e espontânea esse espaço intermitente e plural que é a vida" ${ }^{11}$. De acordo com "(...) o que se poderia chamar o "programa" do romantismo: a artificialidade da construção filosófica deve ser "devolvida" à vida, transformando-se em obra de arte. O homem tem de ser ao mesmo tempo filosofia e vida, "vida ideal" e "filosofia real" - "vivente teoria da vida" (SUZUKI, M. 1998, p. 97).

Com efeito, através de sua escrita fragmentária F. Schlegel desloca a filosofia para um campo mais poético, em consonância com sua proposta de integrar diferentes gêneros discursivos, a fim de construir uma espécie de gênero romântico universal e infinito, sensível à forma como as reflexões nascem, se transformam e à espontaneidade da consciência em sua ampla vivacidade. A escrita fragmentária privilegia o sentido em constante via de formação. Com isso ela traz consigo não apenas aquilo que é explícito, mas também o que permanece apenas silencioso e só pode ser vislumbrado obliquamente. Além de comportar o poético e o filosófico, o fragmento é uma criação que reflete a forma dispersa e intermitente dos fluxos da consciência, e com suas lacunas instiga a imaginação, convocando seu leitor a compor de forma mais livre e participativa sua leitura e até a reconstrução de seu sentido.

Mais que levar o pensamento filosófico à vida, a poesia complementa a filosofia, que, por sua vez, eleva a poesia com a desenvoltura de sua clareza espiritual.

Conforme Márcio Suzuki, para Schelling (1775 - 1854) “a filosofia 'nasceu e foi nutrida pela poesia', então é de se esperar que, quando estiverem plenamente concluídas, a filosofia e 'todas as ciências que são conduzidas pela poesia até a perfeição... voltarão a desaguar, como rios separados, no oceano universal da poesia, de onde elas provieram"” (SUZUKI, M. 2001, p. 12)

Linguagem e mitologia (uma forma de discurso poético), remontam a formação do homem desde um passado, por assim dizer, pré-consciente, em que a imaginação e a intuição tinham um papel preponderante na criação, passado que no

\footnotetext{
${ }^{10}$ Embora reconhecesse a possibilidade e as vantagens da filosofia frequentar e refletir sobre as experiências da poesia, Kant considerava desnecessária e até prejudicial a aproximação excessiva entre elas, pois a filosofia poderia contaminar a sofisticação abstrata de seu arcabouço conceitual com outras formas mais sensíveis de linguagem, que não contribuem para a forma lógica de seu discurso. No mais, para ele a relação estreita entre poesia e filosofia foi salutar apenas enquanto essa ainda não tinha desenvolvido suficientemente seu vocabulário específico: "Os primeiros filósofos foram poetas. É que foi preciso tempo até descobrir palavras para os conceitos abstratos; por isso, no início os pensamentos supra-sensíveis eram representados sob imagens sensíveis [...] Em virtude da pobreza da linguagem, naquela época só se podia filosofar em poesia" (KANT apud Suzuki, 1998, p $55)$

11 Para os românticos, segundo Suzuki, "A filosofia "estanca e tem de estancar" diante da vida, "pois a vida consiste exatamente nisto, que não pode ser compreendida [begriffen]". A vida não pode ser alcançada por nenhum conceito (Begriffe). Diante desse "inefável" (Ein Unaussprechliches), a filosofia deve deixar de ser uma pálida visão esquemática, um produto artificial (Kunstprdukt), para se tornar saber efetivo, uma obra de arte (Kunstwerk). Fiel à doutrina-da-ciência, o romantismo afirma que o sistema do espírito humano tem de ser reinventado a cada vez; mas - adendo propriamente romântico - toda filosofia é "individual", mescla de "filosofia e a-filosofia", e só assim a própria doutrina-da-ciência ou filosofia da filosofia se torna filosofia efetiva" (SUZUKI, M. 1998, p. 96).
}

CANDIDO, Gisele Batista. Encontros e desencontros: uma breve reflexão sobre o longo diálogo entre o poético e o filosófico. Griot : Revista de Filosofia, Amargosa - BA, v.18, n.2, p.114-128, dezembro, 2018. 
entanto frequenta e compõe subterraneamente as conquistas racionais de nossa consciência atual. Uma vez que depende da linguagem para sua constituição, a filosofia não é capaz de segregar completamente de sua prática essa característica pré-cognitiva da linguagem, e ignorar essa presença a faz menos consciente de seu próprio exercício. Diante dessa constatação, F. Schlegel considera imprescindível o estudo da linguagem, inclusive em suas formas tácitas e rudimentares, para, com isso, refletir criticamente sobre a própria filosofia e o homem em sua integralidade. Tanto o mito quanto a linguagem carregam em si a passagem da inconsciência para a consciência que precede e perfaz a história da própria consciência e da razão.

Sobre essa característica da linguagem, Schelling também escreve:

Uma vez que, sem linguagem, não apenas a consciência filosófica, mas a consciência humana não pode absolutamente ser pensada, o fundamento da linguagem não pode ter sido estabelecido com consciência, e, no entanto, quanto mais profundamente nela penetramos, mais determinadamente se descobre que sua profundidade supera de muito longe a da mais consciente das criações. (SCHELLING, Einleitung in die Philosophie der Mythologie. Werke, VI, p. 54 apud SUZUKI, 1998, p. 209).

Quando aborda a origem da linguagem, Schelling reconhece com reservas que ela pode ser vista como uma espécie de mitologia desbotada ${ }^{12}$, que sacrifica a originalidade de sua força simbólica em prol de uma universalidade esquematizante. O mito, por sua vez, será caracterizado por ele segundo essa força simbólica que falta à linguagem. Rubens Rodrigues Torres Filho escreve a respeito do valor simbólico do mito em Schelling, retomando a influência que Goethe exerceu sobre ele:

Ao recomendar a Schelling, que acabava de se transferir para a
Universidade de Würzburg, o pintor romântico Martin Wagner, natural
daquela cidade, solicitando o apoio que fosse possível, material e
intelectualmente, para favorecer o desenvolvimento do talento que se
revelava, Goethe lhe escreve, pois, na data de 29 de novembro de 1803 : "Se
puder fazê-lo compreender a diferença entre tratamento alegórico e
simbólico, você será seu benfeitor, pois tanta coisa gira em torno desse
eixo". O pedido estava bem endereçado. Schelling, em sua laboriosa
velhice, foi o pensador que mais se empenhou, ao longo de toda Filosofia
da mitologia (a partir de 1842 ), no insistente combate à interpretação
alegórica do mito- herança renitente dos estóicos e na afirmação reiterada
de que o mito fala por si mesmo e de si mesmo: não fala de outra coisa.
Mas já na época, tantos anos antes, já está de posse do conceito de
símbolo, nesse mesmo sentido. Ao receber a carta de Goethe, prepara-se,
justamente, para ministrar pela segunda vez seu curso de Filosofia da
Arte, pronunciado em Iena no inverno anterior, onde ensina o caráter
eminentemente simbólico das figuras dos deuses. (FILHO, R. R. T. 2004,
p. 110).

Por sua vez, F. Schlegel não estabelece de forma absoluta nenhuma hierarquia

\footnotetext{
12 "Quase se é tentado a dizer: a própria linguagem é apenas uma mitologia desbotada [verblichene], nela se conservando apenas em diferenças abstratas e formais aquilo que a mitologia ainda conserva em diferenças vivas e concretas" (SCHELLING, Einleitung in die Philosophie der Mythologie. Werke, VI, p. 54 apud SUZUKI, 1998, p. 209).
}

CANDIDO, Gisele Batista. Encontros e desencontros: uma breve reflexão sobre o longo diálogo entre o poético e o filosófico. Griot : Revista de Filosofia, Amargosa - BA, v.18, n.2, p.114-128, dezembro, 2018. 
de precedência ou superioridade entre mitologia e linguagem. Antes, ele as compreende como formas complementares de uma mesma experiência espiritual espirituosa do homem, o chiste. No limite, ele pensa a mitologia como uma espécie de linguagem de apelo singular, e a linguagem como uma mitologia em potencial. Essa diferença relativa entre ambas seria superada quando, conforme o programa romântico, poesia e filosofia se tornassem uma coisa só ${ }^{13}$. Animado por essa disposição, F. Schlegel lança um olhar poético sobre a história da filosofia e procura pensá-la como um grande sistema mitológico. Considerando sobretudo aquilo que escapa à intenção explícita de cada filósofo e também aquilo que os inspira - os movimentos inconscientes que atravessam as construções especulativas, animam a consciência e ganham uma roupagem racional conforme o arbítrio de cada um -, ele vê a filosofia de cada autor como um mito que continua e constitui, ao seu modo, uma grande narrativa mítica. Nas palavras de Márcio Suzuki:

Para ele [F. Schlegel], as obscuridades que os filósofos tentaram solucionar,
as controvérsias em que se enredaram, as passagens instigantes que
colheram nos sistemas anteriores fazem parte de uma grande narrativa
mítica que é transmitida e transformada de geração em geração: "Muitas
controvérsias intricadas da filosofia moderna são como as sagas e os deuses
da poesia antiga. Reaparecem em todo sistema, mas transformados"
(SUZUKI, 1998, p. 227).

Como podemos observar, a radicalidade da aproximação entre poesia e filosofia sugerida por esses dois autores nos lembra, em muitos momentos, aquela simbiose entre esses discursos cultivada nos versos de Homero, nas tragédias gregas, nas obras que precediam os diálogos platônicos e tantos outros que também contribuíram para a especificação da filosofia. Nesse ínterim, em oposição à perspectiva que trata os mitos apenas como uma antecipação alegórica rudimentar de experiências filosóficas, Schelling vê no poder simbólico dos mitos a mesma força que as Idéias tem para filosofia: "As Idéias na filosofia e os deuses na arte são o mesmo" (SCHELLING, Apud. FILHO, R. R. T. 2004, p. 111). Em uma disposição análoga, F. Schlegel subverte certo olhar filosófico, que via a mitologia como uma mera tentativa pré-filosófica de explicar o mundo, e considera a possibilidade de se pensar a história da filosofia como uma grande narrativa mítica.

O movimento Romântico trilha, de certa forma, um caminho inverso ao de Platão. Enquanto esse último procurava refletir sobre as virtudes da filosofia ao distanciar-se da poesia, os românticos almejavam a reaproximação desses dois discursos e entreviam esse enlace como um futuro promissor para a filosofia.

Como podemos observar, o estudo do diálogo entre poesia e filosofia pode revelar uma profunda relação com a constituição intrínseca e histórica da filosofia e com as demandas mais íntimas do próprio ser humano.

É verdade que, nesse curto ensaio, optamos estrategicamente por um recorte

\footnotetext{
${ }^{13}$ Suzuki escreve sobre essa questão em Schlegel: "No fundo, a mitologia também pode e deve ser pensada como uma linguagem: "Uma nova mitologia surgirá: isso não significa outra coisa senão que surgirá uma nova linguagem." Mas também o inverso é verdadeiro: no momento em que "poesia e filosofia se tornarem uma coisa só, então a humanidade será uma única pessoa" e "talvez a própria linguagem se torne mitologia". No ponto máximo de fusão de poesia e filosofia, não haveria nem preponderância da linguagem sobre o mito, nem do mito sobre a linguagem." (SUZUKI, 1998, p. 212).
}

CANDIDO, Gisele Batista. Encontros e desencontros: uma breve reflexão sobre o longo diálogo entre o poético e o filosófico. Griot : Revista de Filosofia, Amargosa - BA, v.18, n.2, p.114-128, dezembro, 2018. 
restrito e uma abordagem pontual para evidenciar as oscilações e salientar alguns movimentos específicos dentro desse diálogo. Entretanto, as relações que se revelam, até mesmo nesse recorte limitado, sugere que não é arbitrário pensar que, desde seus primeiros gestos, a filosofia nunca deixou de se apropriar, tematizar, frequentar, divergir, refletir, enfim, dialogar com a poesia.

Nem nos momentos que marcaram o princípio e o auge de sua especificação, o discurso filosófico se viu totalmente desvinculado do poético. Diante da precedência dessa relação, mesmo aqueles filósofos que, por indiferença ou repulsa, abstém-se de considerar a dimensão poética, marcam uma posição nesse diálogo. Nesse sentido, considerando a escolha desses filósofos que optam por seguir vias estritamente racionais, como se tal opção lhes garantissem clareza e assim a eliminação de todo e qualquer resquício poético de seus discursos, em contrapartida à tal posição, cumpre lembrar das palavras de Adorno e Horkheimer em a Dialética do esclarecimento:

\begin{abstract}
Quanto mais a maquinaria do pensamento subjuga o que existe, tanto mais cegamente ela se contenta com essa reprodução. Desse modo, o esclarecimento regride à mitologia da qual jamais soube escapar. Pois, em suas figuras, a mitologia refletira a essência da ordem existente - o processo cíclico, o destino, a dominação do mundo - como a verdade e abdicara da esperança. Na pregnância da imagem mítica, bem como na clareza da fórmula científica, a eternidade do factual se vê confinada e a mera existência expressa como o sentido que ela substitui. $O$ mundo como um gigantesco juízo analítico, o único sonho que restou de todos os sonhos da ciência, é da mesma espécie que o mito cósmico que associava a mudança da primavera e do outono ao rapto da Perséfone. A singularidade do evento mítico, que deve legitimar o evento factual, é ilusão." (ADORNO, T; HORKHEIMER, 1985, p. 39).
\end{abstract}

Ao examinar as oscilações e movimentos do diálogo entre os discursos poético e filosófico, podemos notar que, quanto mais aberto ao poético é o pensamento do filósofo, mais flexível, diversificado e global são suas reflexões. É possível reconhecer, inclusive, no processo de especialização das ciências, na potencialização de seu exercício e na restrição de seu campo, analogias e ligações com o ímpeto de singularização do discurso filosófico em detrimento do poético.

Os meandros da relação entre poesia e filosofia não revelam apenas as caracterizações e o destino dessas duas empresas, mais que isso, alinhavado a esse diálogo está o destino do próprio ser humano que se vê constantemente arrebatado pelas tensões entre a vida e o pensamento, intuição e razão. Não estamos dizendo com isso que, de uma forma simplista, a vida se identifica exclusivamente com a poesia e o pensamento com a filosofia. Desde o princípio os dois discursos estão interligados e dificilmente se estabelecem de forma pura, sem que um se insinue, mesmo que por negação, no outro. Outrossim, vida e pensamento compartilham de uma intimidade inalienável, pois assim como é indispensável que estejamos vivos para que possamos pensar, também experimentamos a vida através do pensamento, ou melhor, pensar é também uma forma de viver. Atentar para os modos como o equilíbrio entre eles se sustenta é pensar a própria formação da filosofia e do homem, que, como um coração vivo, pulsa, alternando momentos de contração (delimitação e especialização) e de distensão (expansão e flexibilidade). Separar a vida do pensamento, assim como separar o poético do filosófico, é agir arbitrariamente e 
provisoriamente. A filosofia no limite tem que ceder às experiências poéticas, para que sua fala não se esgote nos limites de suas próprias possibilidades abstratas. Um pensamento que não toca a vida é um pensamento limitado à abstração de seu exercício. Permanecer no mundo conceitual pode nos trazer a segurança dos postulados claros e unívocos, mas essas certezas serão estéreis se não tocarem o solo da experiência mundana, se ficarem limitadas à segurança abstrata. Podemos, no entanto, aceitar o pensamento como uma extensão da vida, por exemplo, então fará mais sentindo pensar na complementaridade do que na cisão entre esses discursos. A forma como cada filosofo acolhe a poesia em suas reflexões determina, em certa media, o teor de sua obra.

Enfim, como Pessoa sustentava, embora a filosofia e poesia sejam discursos distintos, existe um vínculo de complementariedade entre eles que os caracterizam e os unem inaliavelmente. 


\section{Referências}

ADORNO, T; HORKHEIMER. Dialética do esclarecimento. Rio de Janeiro: Jorge Zahar Editor, 1985.

BENJAMIN, W. Ensaios reunidos: escritos sobre Goethe. São Paulo: Editora 34, 2009.

ECKERMANN. Conversações com Goethe nos últimos anos de sua vida. São Paulo: Unesp, 2016.

FILHO, R. R. T. Ensaios de filosofia ilustrada. São Paulo: Iluminuras,2004.

GOETHE, J. W. Fausto - Uma tragédia. Primeira Parte. São Paulo: Editora 34, 2010. Os anos de aprendizagem de Wilhelm Meister. São Paulo: Editora 34, 2012.

HÖLDERLIN, F. Hipérion ou o eremita na Grécia. São Paulo: Nova Alexandria, 2003. HESÍODO. Teogonia - A origem dos deuses. São Paulo: Iluminuras, 1995.

HOMERO. Ilíada. Rio de Janeiro: Nova Fronteira, 2012.

Odisséia. Rio de Janeiro: Ediouro, 2001.

JAEGER, W. Paideia - a formação do homem grego. São Paulo: Martins Fontes, 2013.

LAERCIO, D. Vidas de los filósofos más ilustres. Tomo II. Madrid: Imprenta Real, 1792.

LUKÁCS. A alma e as formas. Belo Horizonte: Autêntica, 2015.

NAGY, G. Homeric Poetry and Problems of Multiformity: The "Panathenaic Bottleneck" in Classical Philology no. 96 - 2, 2001.

OLIVEIRA, C. Intrudução in PLATÃO, Íon. Belo Horizonte: Autêntica, 2011.

PESSOA, F. Alberto Caeiro - Poesia completa. São Paulo: Companhia das Letras, 2001.

PLATÃO. A república. São Paulo: Nova Cultural, 1997.

Íon. Belo Horizonte: Autêntica, 2011.

SCHLEGEL. Conversa sobre poesia. São Paulo: Iluminuras, 1994.

$O$ dialeto dos fragmentos. São Paulo: Iluminuras, 1997.

SCHELLING. Filosofia da arte. São Paulo: Edusp, 2001.

SILVA. F. L. Mito e razão na "Odisséia" disponível em: Portal Arethusa. http://arethusa.fflch.usp.br/node/36_ Acesso em: 13/04/2018

SUZUKI, M. A ciência simbólica do mundo in poetas que pensaram o mundo. São Paulo: Cia das Letras, 2005.

A forma e o sentimento do mundo. São Paulo: Ed. 34, 2014.

Filosofia da arte ou arte da filosofia? in SCHELLING, Filosofia da arte. São Paulo: 2001.

O gênio romântico. São Paulo: Iluminuras, 1998.

Os anos de aprendizado de Goethe in Revista Discurso. no.42 ano: 2012

TOLLE, O. Suplemento à poética de Aristóteles in Revista Trans/Form/Ação. no. 23. ano: 2000

WULF. A invenção da natureza: a vida e as descobertas de Alexander Von Humboldt. São Paulo: Planeta, 2016.

Autor(a) para correspondência: Gisele Batista Candido, Universidade de São Paulo, Faculdade de Filosofia, Letras e Ciências Humanas, R. do Lago, 717 - Butantã, CEP 03178-200, São Paulo - SP, Brasil.giselebc@gmail.com 